\title{
Antidiabetic effects of bitter gourd extracts in insulin-resistant $\mathrm{db} / \mathrm{db}$ mice
}

\author{
Sandra D. Klomann ${ }^{1 *}$, Andreas S. Mueller ${ }^{2}$, Josef Pallauf ${ }^{3}$ and Michael B. Krawinkel ${ }^{1 *}$ \\ ${ }^{1}$ Institute of Nutritional Sciences, Justus Liebig University Giessen, Wilhelmstrasse 20, 35392 Giessen, Germany \\ ${ }^{2}$ Preventive Nutrition Group, Institute of Agricultural and Nutritional Sciences, Martin Luther University Halle Wittenberg, \\ Von-Danckelmann-Platz 2, 06120 Halle/Saale, Germany \\ ${ }^{3}$ Department of Animal Nutrition and Nutritional Physiology, Interdisciplinary Research Centre, Justus Liebig University Giessen, \\ Heinrich-Buff-Ring 26-32, 35392 Giessen, Germany
}

(Received 2 March 2010 - Revised 28 May 2010 - Accepted 1 June 2010 - First published online 9 July 2010)

Bitter gourd (BG, Momordica charantia) exerts proven blood glucose- and body weight-lowering effects. To develop an effective and safe application, it is necessary to identify the bioactive compounds and biochemical mechanisms responsible for these effects in type 2 diabetes. A total of forty-five 4-week-old male $\mathrm{db} / \mathrm{db}$ mice were assigned to five groups of nine each. The mice were given sterile tap water as a control, a whole fruit powder, the lipid fraction, the saponin fraction or the hydrophilic residue of BG at a daily oral dosage of $150 \mathrm{mg} / \mathrm{kg}$ body weight for 5 weeks, respectively. Weight gain was significantly decreased in all the BG-treated groups $(P \leq 0 \cdot 05)$. Glycated Hb levels were the highest in the control mice compared with all the four BG-treated mice $(P=0.02)$. The lipid fraction had the strongest effect, and it tended $(P=0.075)$ to reduce glycated $\mathrm{Hb}$ levels from $9.3 \%$ (control mice) to $8.0 \%$ (lipid fraction-treated mice). The lipid and saponin fractions reduced lipid peroxidation of adipose tissue significantly $(P \leq 0 \cdot 01)$. Additionally, the saponin fraction and the lipid fraction reduced protein tyrosine phosphatase 1B (PTP 1B) activity in skeletal muscle cytosol by $25 \%(P=0.05)$ and $23 \%(P=0.07)$, respectively. PTP 1B is the physiological antagonist of the insulin signalling pathway. Inhibition of PTP 1B increases insulin sensitivity. This is the first study to demonstrate that BG is involved in PTP 1B regulation, and thus explains one possible biochemical mechanism underlying the antidiabetic effects of BG in insulin resistance and type 2 diabetes.

Bitter gourd: Diabetes: Protein tyrosine phosphatase 1B: Obesity

There are two main and several minor types of diabetes mellitus. Of diabetic patients, 5\% suffer from type 1 diabetes with absolute insulin deficiency, while about $90 \%$ of all diabetics are affected by type 2 diabetes, which is associated with insulin resistance and obesity. The prevalence of obesity and diabetes mellitus is increasing worldwide. A few decades ago, mainly the industrialised countries were affected, but presently, diabetes mellitus is a problem in developing countries also $^{(1)}$. However, the population of developing countries often has no access to adequate medical care and drugs due to economic or infrastructure reasons. Therefore, nutrition and dietary measures play a crucial role in the treatment of insulin resistance in these countries. Vegetables and fruits with antidiabetic effects may contribute to the improvement of metabolic control.

In traditional Asian medicine, the bitter gourd (BG, Momordica charantia) is known for its blood glucoselowering effects in hyperglycaemic patients. Powder and extracts of the fruit, as well as teas from the stems and leaves of the plant, are used ${ }^{(2-5)}$. In vivo studies, especially those done on rodents with type 1 diabetes, but also a few studies done on insulin-resistant rodents demonstrated the blood glucose-lowering effects of $\mathrm{BG}$ and its extracts.
However, due to the many different experimental models and extracts, it is not sufficiently clear what substances or substance groups are mainly responsible for the blood glucose-lowering effect of BG and what biochemical mechanisms underlie this effect. Saponins, triterpenes, conjugated fatty acids and other substances which, depending on the experimental design, inhibit the intestinal absorption of monosaccharides $^{(6)}$, enhance insulin secretion ${ }^{(3)}$ or increase insulin sensitivity of insulin-dependent tissues ${ }^{(7,8)}$ are discussed.

One possible explanation for the increased insulin sensitivity is a decreased activity of protein tyrosine phosphatase 1B (PTP 1B). PTP 1B acts as a physiological antagonist of the insulin receptor and its signal by dephosphorylating both the insulin receptor and the insulin receptor substrates ${ }^{(9,10)}$. Increased PTP 1B levels or an increased activity of this enzyme were found in insulin-resistant and obese patients ${ }^{(11)}$. Mohammad et al. ${ }^{(12)}$ showed that untreated Zucker fatty rats exhibit a $200 \%$ increased PTP 1B activity in the skeletal muscle in comparison with their healthy companions. Increased PTP 1B levels were also found in insulin-resistant obese patients ${ }^{(11)}$. In contrast, non-diabetic mice without PTP 1B gene (PTP 1B $-/-$ mice) showed increased insulin sensitivity and, even under a high-fat diet, no

Abbreviations: BG, bitter gourd; PTP 1B, protein tyrosine phosphatase 1B; TBA-RS, thiobarbituric acid-reactive substances.

* Corresponding authors: S. D. Klomann, fax +496419939 039, email sandra.d.klomann@ernaehrung.uni-giessen.de; M. B. Krawinkel, email michael.krawinkel@ ernaehrung.uni-giessen.de 
weight gain $^{(13)}$, a reduced fat cell mass and an increased $\mathrm{BMR}^{(14)}$. Several studies suggest that the reduction in PTP $1 \mathrm{~B}$ expression and activity is sufficient to enhance the insulin signalling pathway and to improve insulin sensitivity ${ }^{(15)}$. Therefore, the inhibition of PTP $1 \mathrm{~B}$ or the reduction in PTP $1 \mathrm{~B}$ levels is a potential target for the prevention and treatment of insulin resistance and type 2 diabetes. Substances that reduce PTP $1 \mathrm{~B}$ expression or activity are more and more being considered as important.

The aim of the present study was to investigate the molecular aspect of the antidiabetic effects of different BG fractions in type 2 diabetic $\mathrm{db} / \mathrm{db}$ mice and in particular their tissue-specific effect on PTP 1B regulation. Additionally, we measured the concentration of thiobarbituric acid-reactive substances (TBA-RS) as a marker for oxidative stress and damage in the liver, adipose tissue and skeletal muscle.

\section{Materials and methods}

\section{Preparation of bitter gourd extracts}

The saponin fraction, the lipid fraction and the hydrophilic residue were extracted using the methods published by Oishi et al. $^{(6)}$ and Chao \& Huang ${ }^{(16)}$ combinedly.

Fresh fruits, described as green BG by Chao \& Huang ${ }^{(16)}$, were grown in Frankfurt/Main, Germany. The fruits were cut, freeze-dried (Gamma 1-20; Christ, Osterode, Germany) and ground. Then, $200 \mathrm{~g}$ of homogeneous powder were stirred in 3 litres of ethyl acetate in the dark for $2 \mathrm{~h}$ and filtered. Using the rotary evaporator (Laborota digitally 4002; Heidolph, Schwabach, Germany), the ethyl acetate was evaporated at $35^{\circ} \mathrm{C}$ to obtain the lipid fraction with a concentration of $3.2 \%$ of the whole fruit on a DM basis. The non-ethyl acetate-soluble filter residue was again stirred in 3 litres of methanol in the dark for $2 \mathrm{~h}$ and filtered. The filtrate was reduced to a dry residue in a rotary evaporator at $42^{\circ} \mathrm{C}$, and the dry residue was dissolved in $250 \mathrm{ml}$ of distilled water and $250 \mathrm{ml}$ of $n$-butanol. The water phase and the $n$-butanol phase were separated, and were then evaporated at $40^{\circ} \mathrm{C}$ to obtain the hydrophilic residue $(12.2 \%$ of $\mathrm{DM})$ and the saponin fraction $(4.2 \%$ of DM). Concentrations of the fractions were similar to the data reported in the literature ${ }^{(6,17)}$.

\section{Animal model and experiment}

A total of forty-five 4-week-old male $\mathrm{db} / \mathrm{db}$ mice (BKS. Cg- + Leprdb/+Leprdb/01aHsd; Harlan Winkelmann GmbH, Borchen, Germany) were assigned to five groups of nine each. For the 5-week trial, the mice were kept individually in plastic cages at $22^{\circ} \mathrm{C}$ and under a $12 \mathrm{~h}$ day- $12 \mathrm{~h}$ night cycle. The mice had free access to a self-made non-purified standard diet (Table 1) with all nutrients at the level of the National Research Council ${ }^{(18)}$ recommendations (Table 2) and to drinking-water.

In addition, the mice were given the whole fruit powder, the lipid fraction, the saponin fraction or the hydrophilic residue of BG at a daily oral dosage of $150 \mathrm{mg} / \mathrm{kg}$ body weight for 5 weeks. The whole fruit powder and the extracts were dissolved in sterile tap water $(45 \mathrm{mg} / \mathrm{ml})$, and were given via stomach feeding. The lipid fraction was dispersed to ensure
Table 1. Composition of the self-made standard diet

\begin{tabular}{|c|c|}
\hline Ingredient & $\mathrm{g} / \mathrm{kg}$ diet \\
\hline Wheat (Weil, Langgöns, Germany) & 241.9 \\
\hline Maize (Weil) & $200 \cdot 0$ \\
\hline Barley (Weil) & $156 \cdot 0$ \\
\hline Soyabean meal (Weil) & $220 \cdot 0$ \\
\hline Wheat bran (Weil) & $80 \cdot 0$ \\
\hline Oats (Weil) & $70 \cdot 0$ \\
\hline Sunflower oil (local market, Germany) & $15 \cdot 0$ \\
\hline $\begin{array}{l}\text { Mineral premix }{ }^{*} \text { (all salts obtained from } \\
\text { Sigma-Aldrich, St. Louis, MO, USA) }\end{array}$ & $14 \cdot 0$ \\
\hline $\begin{array}{l}\text { Vitamin premix† (all vitamins obtained } \\
\text { from Roche, Basel, Switzerland) }\end{array}$ & 0.8 \\
\hline I-Lys HCl* (Evonic, Essen, Germany) & 0.3 \\
\hline DL-Met* (Evonic) & $2 \cdot 0$ \\
\hline Total & $1000 \cdot 0$ \\
\hline
\end{tabular}

* Minerals and amino acids were added by taking the native concentrations of the minerals and amino acids in wheat, maize, barley, soyabean meal, wheat bran and oats into consideration to achieve the recommended amounts ${ }^{(18)}$.

†All vitamins were added according to the National Research Council ${ }^{(18)}$ recommendations without correction.

that hydrophobic substances were homogeneously distributed in the water. The control group was given sterile tap water.

After 5 weeks and fasting for $6 \mathrm{~h}$, the mice were anaesthetised with $\mathrm{CO}_{2}$, blood was collected from the heart using EDTA-Monovettes (KABAVETTE ${ }^{\circledR}$; KABE Laboratory $\mathrm{GmbH}$, Nümbrecht-Elsenroth, Germany), and then the mice were decapitated. Liver, skeletal muscle and adipose tissue were immediately frozen in liquid $\mathrm{N}_{2}$ and stored for further analysis at $-80^{\circ} \mathrm{C}$. As a long-term parameter of blood glucose levels, glycated $\mathrm{Hb}$ levels were measured using a test kit (HA1C Kit) and an analyser (Dimension ${ }^{\circledR} \mathrm{Xpand}^{\mathrm{TM}}$ ) obtained from Siemens Healthcare Diagnostics (Eschborn, Germany). Mouse erythrocytes have a lifespan of about $22 \mathrm{~d}^{(19)}$.

Institutional and national guidelines for the care and use of animals were followed, and the protocol of the animal study was approved by the Animal Protection Unit of the Regional Council of Giessen, Germany (reference: V54-19c20/15cGI 19/1).

\section{Determination of protein tyrosine phosphatase $1 B$ activity (Zhu \& Goldstein method)}

PTB 1B activity was determined according to the method of Zhu \& Goldstein ${ }^{(20)}$. Liver, skeletal muscle and adipose tissue were homogenised using buffer A (50 mM-HEPES, $50 \mathrm{~mm}-\mathrm{NaCl}, 0.5 \mathrm{~mm}$-EDTA, 0.1 mM-phenylmethanesulphonylfluoride, $\mathrm{pH} 7 \cdot 2$ ), and were centrifuged (Labofuge 400R, Heraeus Instruments, Hanau, Germany) for $30 \mathrm{~min}$ at $13000 \mathrm{rpm}$ and $2^{\circ} \mathrm{C}$.

Table 2. Macronutrients of the diet and comparison with the National Research Council (NRC) $)^{(18)}$ recommendations

\begin{tabular}{lcc}
\hline & Diet & $\mathrm{NRC}^{(18)}$ \\
\hline DM (\%) & 84.9 & - \\
Crude ash (\% of DM) & 4.5 & - \\
Sugar (\% of DM) & 3.02 & - \\
Protein (\% of DM) & 19.9 & 20.0 \\
Fat (\% of DM) & 4.7 & 5.0 \\
\hline
\end{tabular}


A quantity of $10 \mu \mathrm{l}$ of the cytosolic supernatant was incubated with $240 \mu \mathrm{l}$ of buffer A at room temperature for 5 min. Subsequently, $250 \mu \mathrm{l}$ of buffer A containing $10 \mathrm{mM}-$ $p$-nitrophenylphosphate were added. Due to the activity of PTP $1 \mathrm{~B}, p$-nitrophenylphosphate was dephosphorylated to $p$-nitrophenol. This reaction was stopped after $20 \mathrm{~min}$ using $500 \mu \mathrm{l}$ of a $2 \mathrm{M}-\mathrm{NaOH}$ solution. In an alkaline environment, $p$-nitrophenol changes to $p$-nitrophenolate anion, which is coloured intensely yellow and can be quantified by a photometer (Cary 50 Bio; Varian, Melbourne, Vic, Australia) at $405 \mathrm{~nm}$.

The measurement was repeated with a buffer containing 2 mM-dithiothreitol, a reducing agent, to measure the reversible inhibition of PTP $1 \mathrm{~B}$.

In order to refer PTP 1B activity to the protein content, the protein content of the prepared samples was determined by the Bradford ${ }^{(21)}$ method.

\section{Determination of protein tyrosine phosphatase $1 B$ expression} via Western blot analysis

Skeletal muscle was homogenised using a radioimmunoprecipitation assay lysis buffer $(50 \mathrm{~mm}$-Tris- $\mathrm{HCl}, 150 \mathrm{~mm}-$ $\mathrm{NaCl}, 1 \mathrm{~mm}$-phenylmethanesulphonylfluoride, $1 \mathrm{mm-EDTA}$, $10 \mathrm{~g} / \mathrm{l}$ sodium deoxycholate, $1 \mathrm{~g} / \mathrm{l} \mathrm{SDS}, 10 \mathrm{ml} / \mathrm{l}$ Triton $\mathrm{X}-100$, $\mathrm{pH}$ 7.4), and the protein content was measured by the Bradford $^{(21)}$ method. A quantity of $40 \mu \mathrm{g}$ of the protein was then separated on a $15 \%(\mathrm{v} / \mathrm{v})$ polyacrylamide gel, and the separated proteins were transferred onto a polyvinyldifluoride membrane (PALL BioTrace $0.45 \mu \mathrm{l}^{\mathrm{TM}}$ ) via a semi-dry blotting technique. After blocking and washing, first the PTP 1B antibody and then the secondary antibody, linked to an alkaline phosphatase, were added. Blots were developed using a Mg-containing reaction buffer with nitro blue tetrazolium chloride and 5-bromo-4-chloro-3-indolyl phosphate. Optical density of the protein bands was measured using GenTools from SynGene (Synoptics Limited, Cambridge, UK).

\section{Determination of protein tyrosine phosphatase $1 B$ gene expression via RT-PCR}

Skeletal muscle RNA was isolated according to the method described by Chomczynski \& Sacchi ${ }^{(22)}$. To analyse RNA purity and quantity, RNA was dissolved in nuclease-free water and measured photometrically (Genesys $10 \mathrm{UV}$; Thermo, Bonn, Germany) at 260 and $280 \mathrm{~nm}$. RNA with a quotient of the absorbances between 1.6 and 1.8 at 260 and $280 \mathrm{~nm}$ was considered pure, and was used for further analyses. For further quality control, RNA was separated electrophoretically on a $1.5 \%$ agarose gel.

For complementary DNA synthesis, a kit obtained from MBI-Fermentas (Revert Aid ${ }^{\mathrm{TM}}$ First, Strand complementary DNA Synthesis Kit; Fermentas, St Leon-Rot, Germany) was used.

For gene-specific PCR, the following forward (fw) and reverse (rev) primers were used for $\beta$-actin and PTP 1B genes:

$\beta$-Actin fw $\left(5^{\prime} \rightarrow 3^{\prime}\right)$ : TGT TAC CAA CTG GGA CGA CA

$\beta$-Actin rev $\left(5^{\prime} \rightarrow 3^{\prime}\right)$ : TCT CAG CTG TGG TGG TGA AG

PTP $1 \mathrm{~B}$ fw $\left(5^{\prime} \rightarrow 3^{\prime}\right):$ GAT GGA GAA GGA GTT CGA GGA G PTP 1B rev $\left(5^{\prime} \rightarrow 3^{\prime}\right)$ : CCA TCA GTA AGA GGC AGG TGT

\section{Determination of thiobarbituric acid-reactive substances}

The concentration of TBA-RS, in tissues and organs is a marker for oxidative stress, which is normally increased in diabetes. Products of lipid peroxidation and degradation, such as malondialdehyde, react with thiobarbituric acid, which can then be quantified photometrically (Cary 50 Bio; Varian) at $532 \mathrm{~nm}$. We measured the concentration of TBARS in the cytosol of skeletal muscle, adipose tissue and liver according to the method described by Wong et al. ${ }^{(23)}$ and modified by Khoschsorur et al. ${ }^{(24)}$.

\section{Statistical analysis}

To test the differences between groups $(P \leq 0.05)$, we performed ANOVA, followed by post hoc testing (two-sided). Differences between the control and all the treated groups $(P \leq 0.05)$ were examined using $t$ tests (two-sided) for unpaired samples. Increase in body weight $(P \leq 0.05)$ was tested using $t$ tests (two-sided) for paired samples. Normal distribution and homoscedasticity were ascertained for all the tests. Correlations between parameters were analysed according to Pearson or Spearman for non-parametric correlations when normal distribution was not given. We used Statistical Package for Social Sciences 17.0 program for Windows (SPSS, Inc., Chicago, IL, USA).

\section{Results}

At the beginning of the study, the mean body weight of the mice (29.2 (SD 0.2) g) did not differ within the five groups. Body weight of all the mice increased significantly $(P<0.0001)$ during the 5-week trial. The control group showed the highest body weight gain from the first week onwards (Fig. 1). After 5 weeks, body weight was significantly lower when the mice were given the whole fruit powder $(P=0 \cdot 005)$, the lipid fraction $(P=0 \cdot 007)$, the saponin fraction $(P=0 \cdot 007)$ or the hydrophilic residue $(P=0 \cdot 05)$ in comparison with that of the control mice (Table 3 ).

After 5 weeks, the control group also showed the highest levels of glycated $\mathrm{Hb}$ compared with all the four BG-treated

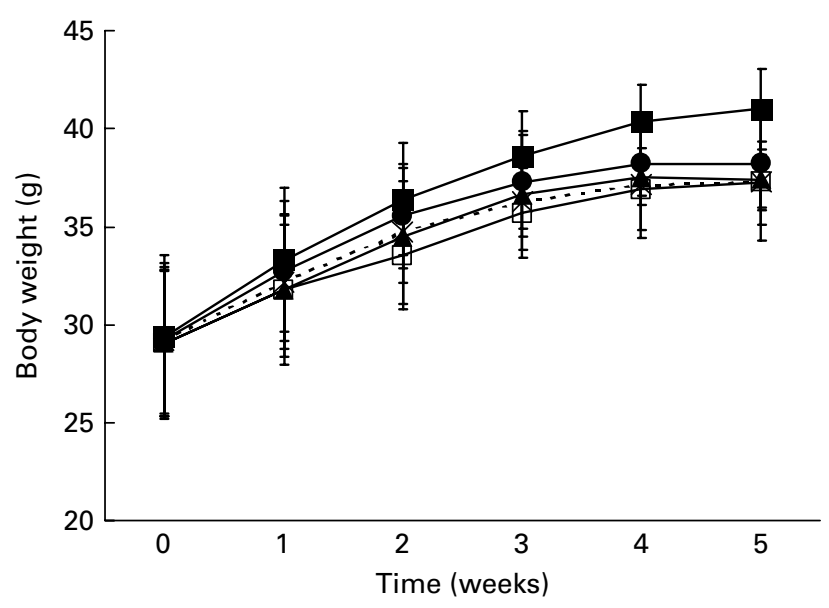

Fig. 1. Body weight gain of the male $\mathrm{db} / \mathrm{db}$ mice during 5 weeks of bitter gourd treatment in comparison with that of the control mice (means and standard deviations). $-\square-$, Control; $-\square-$, whole fruit; $-\boldsymbol{\Delta}-$, lipids; $-\times-$, saponins; - - - hydrophilic residue. 
Table 3. Feed intake, body weight and glycated $\mathrm{Hb}$ of male $\mathrm{db} / \mathrm{db}$ mice after 5 weeks of bitter gourd treatment in comparison with that of the control mice

(Mean values and standard deviations)

\begin{tabular}{|c|c|c|c|c|c|c|c|c|c|c|}
\hline & \multicolumn{2}{|c|}{ Control } & \multicolumn{2}{|c|}{ Whole fruit } & \multicolumn{2}{|c|}{ Lipid fraction } & \multicolumn{2}{|c|}{$\begin{array}{l}\text { Saponin } \\
\text { fraction }\end{array}$} & \multicolumn{2}{|c|}{$\begin{array}{l}\text { Hydrophilic } \\
\text { residue }\end{array}$} \\
\hline & Mean & SD & Mean & SD & Mean & SD & Mean & SD & Mean & SD \\
\hline Feed intake $(\mathrm{g} / \mathrm{d})$ & $17 \cdot 0$ & $2 \cdot 3$ & $18 \cdot 0$ & $2 \cdot 7$ & $16 \cdot 9$ & 1.8 & $16 \cdot 7$ & $4 \cdot 1$ & 17.5 & $3 \cdot 7$ \\
\hline Body weight (g) & 41.0 & $2 \cdot 1$ & $37 \cdot 3^{\star * \star}$ & $2 \cdot 1$ & $37 \cdot 4^{\star \star \star}$ & $3 \cdot 1$ & $37 \cdot 3^{\star \star \star}$ & 1.4 & $38 \cdot 3^{\star *}$ & $2 \cdot 3$ \\
\hline Glycated $\mathrm{Hb}(\%)$ & $9 \cdot 3$ & 0.9 & 8.5 & 0.9 & $8.0^{*}$ & 0.9 & 8.4 & 1.4 & $8 \cdot 3$ & 1.4 \\
\hline
\end{tabular}

Mean values were significantly different from those of the control mice: ${ }^{\star} P \leq 0.1,{ }^{\star \star} P \leq 0.05,{ }^{\star \star \star} P \leq 0.01$.

groups $(P=0 \cdot 02)$. However, the effect on glycated $\mathrm{Hb}$ level for each individual BG-treated group was not statistically significant. The lipid fraction had the strongest effect, and it tended $(P=0.075)$ to reduce glycated $\mathrm{Hb}$ levels from $9.3 \%$ (in control mice) to $8.0 \%$ (in lipid fraction-treated mice) (Table 3). No differences existed in feed intake (Table 3).

Native PTP 1B activity of liver and adipose tissue did not differ between the groups (data not shown). PTP 1B activity of skeletal muscle cytosol was significantly reduced in mice that were given the saponin fraction $(P=0.05)$, and it tended to be lower after treatment with the lipid fraction $(P=0 \cdot 07)$ of BG compared with that of the control group. Mean PTP $1 \mathrm{~B}$ activity was 25 or $23 \%$ lower after the saponin or the lipid treatment, respectively (Fig. 2). The addition of the reducing agent dithiothreitol reversed the inhibition of PTP $1 \mathrm{~B}$ in the saponin-treated mice $(P=0.02)$, indicating a reversible inhibition of the enzyme via oxidation (Fig. 3).

In the lipid-treated mice, dithiothreitol did not increase PTP $1 \mathrm{~B}$ activity of the skeletal muscle cytosol (Fig. 3). This might be due to an irreversible inhibition or due to a decreased expression of the enzyme. Consequently, RT-PCR and Western blot analysis were performed to compare PTP 1B gene expression and PTP 1B expression of the control and lipid fraction-treated mice. Contrary to expectations, there was no significant regulation at the gene (Fig. 4(a)) or protein (Fig. 4(b)) level. Western blot analysis showed even an increase of $40 \%$ rather than a decrease in PTP 1B levels (Fig. 4(b)) in the lipid-treated mice. However, this finding was NS.

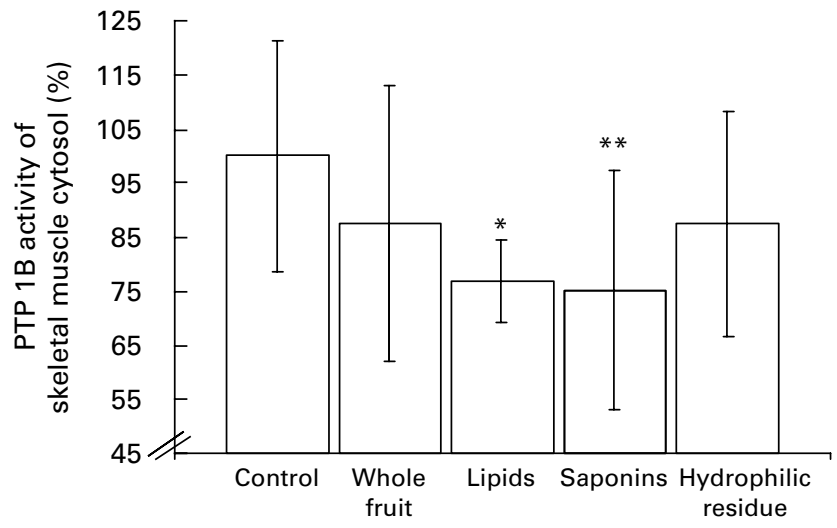

Fig. 2. Native protein tyrosine phosphatase 1B (PTP 1B) activity of skeletal muscle cytosol of the male $\mathrm{db} / \mathrm{db}$ mice after 5 weeks of bitter gourd treatment in comparison with that of the control mice (means and standard deviations). Mean value was significantly different from that of the control mice: ${ }^{\star} P=0.07,{ }^{*} P=0.05$.
Concentrations of TBA-RS were more than $40 \%$ reduced in the adipose tissue of the mice treated with BG saponins $(P=0.005)$ or lipids $(P=0.003)$ compared with those of the control mice (Fig. 5(a)). While BG saponins and lipids had no significant effect on the TBA-RS concentration in the skeletal muscle cytosol, the concentration of TBA-RS in the skeletal muscle cytosol was $65 \%$ lower in the mice treated with the hydrophilic residue of $\mathrm{BG}$ in comparison with that in the control mice $(P=0 \cdot 001)$ (Fig. 5(b)). There was no influence of BG administration on TBA-RS concentration in the liver (data not shown).

\section{Discussion}

There are far more patients suffering from type 2 diabetes mellitus than from type 1 diabetes mellitus. Therefore, investigations on the antidiabetic effects of BG in insulin-resistant and type 2 diabetic rodents are relevant for the development of new applications. Data obtained from in vitro and in vivo studies show positive effects of BG on insulin sensitivity ${ }^{(25,26)}$. However, some results are contradictory ${ }^{(3,27,28)}$, and the knowledge about active substances, the most effective dosage and the biochemical mechanism is still insufficient.

While some in vitro studies showed that 5'-AMP-activated protein kinase activation is involved in the increased glucose uptake of adipocytes or myocytes ${ }^{(29,30)}$, others could demonstrate that BG influences insulin signalling. In these studies, the addition of wortmannin, a specific inhibitor of phosphatidylinositol 3-kinase, to the medium inhibited cellular glucose uptake with or without BG treatment ${ }^{(3,2,27)}$. Thus, it can be assumed that BG influences insulin signalling before the phosphatidylinositol 3-kinase reaction, presumably at the PTP 1B regulation level.

Miura et al. ${ }^{(8)}$ were among the first to prove the antidiabetic effect of $\mathrm{BG}$ in type 2 diabetic animals. A water-soluble extract of BG resulted in significantly $(P \leq 0 \cdot 01)$ lower blood glucose and insulin levels, and improved glucose tolerance and insulin sensitivity in male KK-Ay mice. Regarding the mechanism of the insulin-sensitising effect of BG, they could show that the level of GLUT4 in the cell membrane was $144 \%$ higher in the skeletal muscle of the mice treated with $\mathrm{BG}$ than in that of the control mice ${ }^{(8)}$. Increased GLUT4 recruitment into the cell membrane is the result of increased insulin signalling, starting at the insulin receptor. In this context, Nerurkar et al. ${ }^{(7)}$ could demonstrate that BG juice increased tyrosine phosphorylation of the insulin receptor and of the insulin receptor substrates 1 and 2 in the livers of female mice fed a high-fat diet $(58.0 \mathrm{~kJ} \%$ fat $)$. 


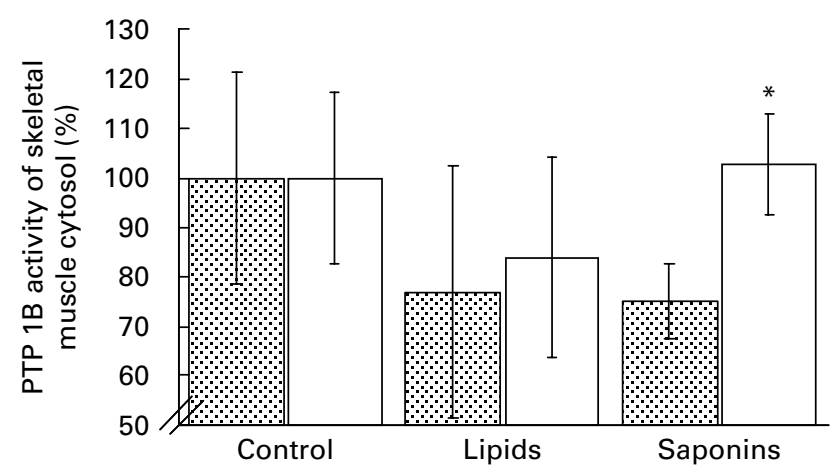

Fig. 3. Protein tyrosine phosphatase 1B (PTP 1B) activity of skeletal muscle cytosol before and after addition of $2 \mathrm{~mm}$-dithiothreitol (DTT) in the male $\mathrm{db} / \mathrm{db}$ mice after 5 weeks of treatment with bitter gourd lipids or saponins in comparison with that of the control mice (means and standard deviations). 圈, $-2 \mathrm{~mm} \mathrm{DTT} ; \square,+2 \mathrm{~mm}$ DTT. *Mean value was significantly different from that before the addition of DTT $(P=0.02)$.

Furthermore, an enhanced interaction of insulin receptor substrate 1 and phosphatidylinositol 3-kinase was observed. Similar results for the effect of BG after the consumption of a high-fat diet (59\% of total energy from fat) on the insulin signalling pathway were reported by Sridhar et al. ${ }^{(31)}$. BG improved both glucose tolerance and insulin sensitivity significantly $(P \leq 0 \cdot 05)$. Western blot analysis showed a significant $(P \leq 0.001)$ increase in insulin-stimulated tyrosine phosphorylation of insulin receptor substrate 1 in the calf muscle.

In the present study, administration of BG extracts reduced body weight gain $(P<0.0001)$ and glycated $\mathrm{Hb}$ levels $(P=0.02)$ in growing $\mathrm{db} / \mathrm{db}$ mice. Greer et $a l .{ }^{(32)}$ published data obtained from 10 -week-old $\mathrm{db} / \mathrm{db}$ mice that not only had increased blood glucose levels but also had increased insulin levels compared with the age-matched control mice, indicating that the mice suffered from insulin resistance. Similar to our control mice, $\mathrm{db} / \mathrm{db}$ mice used in the study done by Greer et $a l .{ }^{(32)}$ had a mean glycated $\mathrm{Hb}$ level of $9.2 \%$, whereas healthy mice had a mean glycated $\mathrm{Hb}$ level of $4.5 \%$. In the present study, 9-week-old control mice had a mean glycated $\mathrm{Hb}$ level of $9.3 \%$. Thus, reduced glycated $\mathrm{Hb}$ levels after BG treatment are the result of increased insulin sensitivity. Hence, the present study provides further evidence (a)

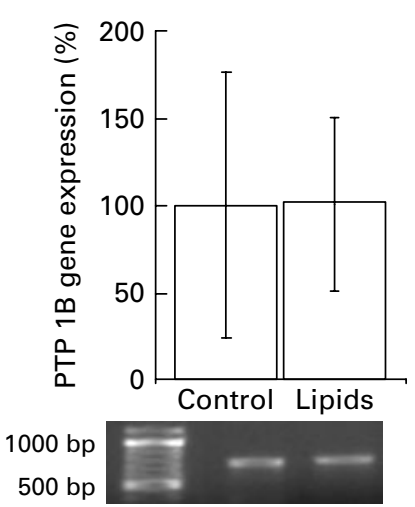

(b)

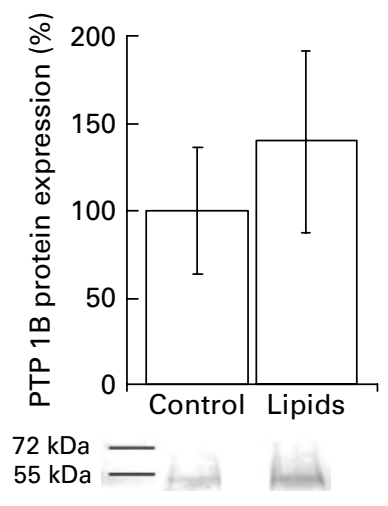

Fig. 4. Protein tyrosine phosphatase 1B (PTP 1B) gene expression (a) and PTP 1B expression (b) (means and standard deviations) in the skeletal muscle cytosol of the male $\mathrm{db} / \mathrm{db}$ mice treated with bitter gourd lipids for 5 weeks in comparison with that of the control mice.
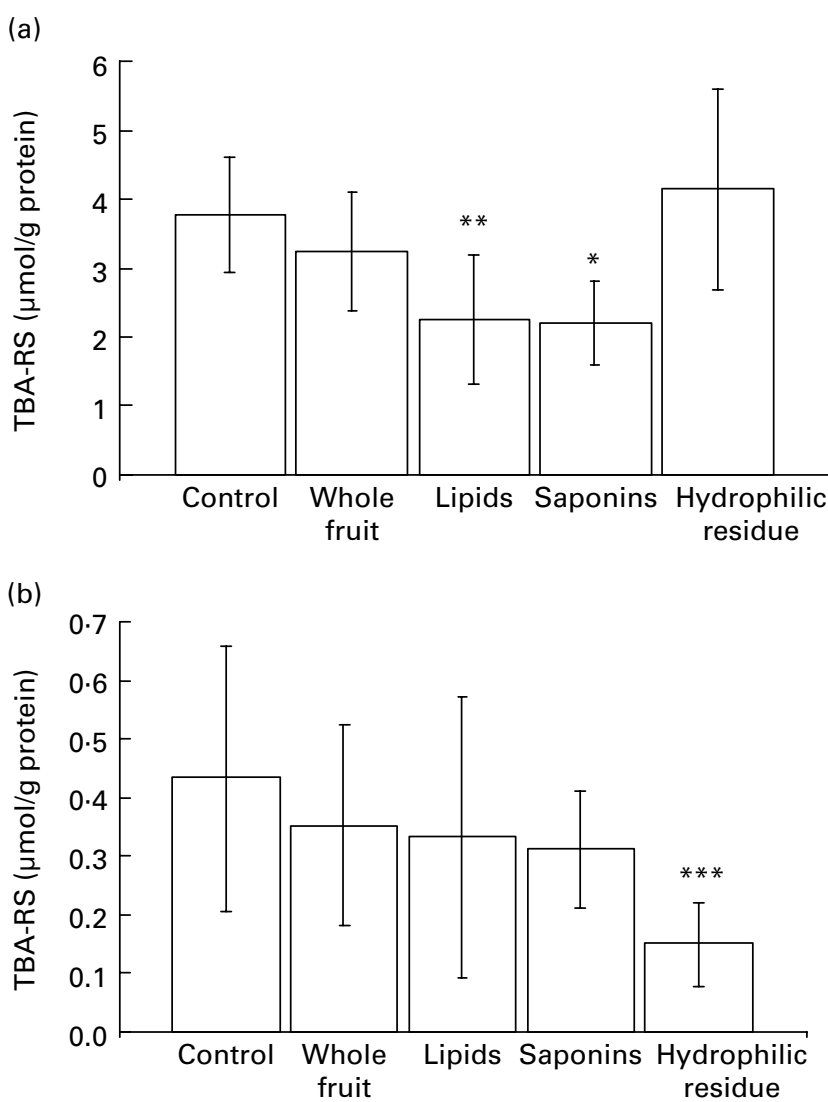

Fig. 5. Concentration of thiobarbituric acid-reactive substances (TBA-RS) ( $\mu \mathrm{mol} / \mathrm{g}$ protein) in adipose tissue (a) and skeletal muscle (b) of the male $\mathrm{db} / \mathrm{db}$ mice after 5 weeks of bitter gourd treatment compared with that of the control mice; data shown as means and standard deviations. Mean value was significantly different from that of the control mice: ${ }^{\star} P=0.005$, ${ }^{\star \star} P=0.003,{ }^{\star \star \star} P=0.001$.

for the insulin-sensitising and antidiabetic effects of BG in type 2 diabetes. As there was no correlation between body weight and glycated $\mathrm{Hb}$ levels (Table 4), the antidiabetic effect of BG cannot be explained by reductions in body weight after BG administration. However, the inhibition of PTP 1B activity in the skeletal muscle cytosol after the administration of the saponin or the lipid fraction of BG provides information on the biochemical mechanism of this antidiabetic effect. Reduced PTP 1B activity is directly associated with

Table 4. Correlations between body weight, glycated $\mathrm{Hb}$ levels, protein tyrosine phosphatase 1B (PTP 1B) activity and concentrations of thiobarbituric acid-reactive substances (TBA-RS) in male $\mathrm{db} / \mathrm{db}$ mice after 5 weeks of bitter gourd treatment and in the control mice

\begin{tabular}{|c|c|c|c|c|}
\hline & \multicolumn{2}{|c|}{ Body weight } & \multicolumn{2}{|c|}{ Glycated $\mathrm{Hb}$} \\
\hline & $r$ & $P$ & $r$ & $P$ \\
\hline Glycated $\mathrm{Hb}$ & 0.025 & 0.874 & 1 & \\
\hline $\begin{array}{l}\text { Native PTP 1B activity } \\
\text { in skeletal muscle cytosol }\end{array}$ & 0.260 & 0.088 & 0.155 & 0.315 \\
\hline $\begin{array}{l}\text { TBA-RS concentration in adipose } \\
\text { tissue }\end{array}$ & 0.165 & 0.284 & 0.098 & 0.529 \\
\hline $\begin{array}{l}\text { TBA-RS concentration in skeletal } \\
\text { muscle cytosol }\end{array}$ & -0.183 & 0.240 & 0.220 & 0.156 \\
\hline
\end{tabular}

$r$, Correlation coefficients. 
increased insulin sensitivity. The insulin signalling pathway and tyrosine phosphorylation of the insulin receptor and its substrates and finally glucose uptake into the cell via GLUT4 can be amplified by the inhibition of PTP $1 \mathrm{~B}^{(9,33)}$. Thus, the down-regulation of PTP 1B activity by BG saponins and lipids may provide mechanistic information for the increased insulin sensitivity and the above-mentioned results $^{(7,8,31)}$. Although saponins are soluble in water, we separated the saponin fraction from the hydrophilic residue using $n$-butanol. Some authors ${ }^{(8,27)}$ mentioned above used aqueous BG extracts presumably containing saponins ${ }^{(34)}$. The insulinsensitising effect of the aqueous BG extracts of these studies may have been at least partly induced by saponins. In view of the present results, hydrophilic substances other than saponins do not seem to be as effective as the saponin fraction in increasing insulin sensitivity. In the present study, mice treated with the hydrophilic residue did not show significant effects with regard to glycated $\mathrm{Hb}$ level or PTP 1B activity. The present study indicates that saponins and the saponin fraction are the most effective water-soluble compounds of BG when treating type 2 diabetic mice. Saponins isolated from Argania spinosa were also shown to enhance insulin signalling via insulin-dependent activation of protein kinase B in hepatoma tissue culture cells ${ }^{(35)}$. Possibly, these findings can also be explained by PTP 1B inhibition, and the insulin-sensitising effect of saponins via PTP $1 \mathrm{~B}$ inhibition is not limited to specific BG saponins, but it is the same for other saponins.

Nevertheless, BG saponins or other substances in the saponin fraction may also improve insulin sensitivity or reduce body weight gain via other mechanisms. For example, it is known that the saponin fraction of BG inhibits intestinal disaccharidases and pancreatic lipase dose dependently ${ }^{(6,36)}$.

The lipid fraction of BG also tended to reduce PTP $1 \mathrm{~B}$ activity of the skeletal muscle cytosol $(P=0.07)$. In contrast to the saponin fraction, the lipid fraction led to an inhibition that was not reversible by dithiothreitol. Contrary to our initial assumption that BG lipids reduce PTP $1 \mathrm{~B}$ expression at either the gene or protein level, the present results show no regulation of PTP $1 \mathrm{~B}$ expression in the mice treated with BG lipids compared with the control mice. The mechanism by which BG lipids inhibit PTP $1 \mathrm{~B}$ activity has not been clarified so far. A possible explanation is that BG lipids inhibit PTP 1B activity irreversibly, which might lead to the slight (NS) up-regulation of the enzyme at the protein level. The cysteine residue 215 at the active site of the enzyme is usually oxidised to sulphenic acid, which leads to a reversible inhibition of PTP 1B. However, the sulphenic acid can be further oxidised to sulphinic and sulphonic acids. These oxidations and the resulting inhibition are irreversible ${ }^{(37)}$. For BG lipids, an irreversible inhibition of PTP $1 \mathrm{~B}$ via oxidation or other mechanisms is most likely to occur.

We found a positive, but NS correlation between PTP 1B activity and body weight (Table 4). Thus, BG lipids and saponins may be able to inhibit PTP 1B independent of the body weight. Although the mechanism is not clarified, it is an important finding that $\mathrm{BG}$ compounds are able to regulate PTP $1 \mathrm{~B}$ in the skeletal muscle of $\mathrm{db} / \mathrm{db}$ mice. Delibegovic et $a{ }^{(38)}$ could prove that a complete or $50 \%$ deletion of muscle-specific PTP $1 \mathrm{~B}$ in mice fed a high-fat $(55 \%(\mathrm{w} / \mathrm{w})$ fat) or a normal diet leads to decreased blood glucose and insulin levels, ameliorated glucose clearance and increased insulin sensitivity without lowering the body weight. These results show that decreased PTP 1B levels of skeletal muscle are able to increase whole body insulin sensitivity independently of the body weight. However, correlation between PTP 1B activity of the skeletal muscle cytosol and glycated $\mathrm{Hb}$ levels was positive, but NS (Table 4). This leads to the conclusion that other mechanisms might also be involved in the antidiabetic effects of BG.

Apart from their effect on PTP 1B regulation, BG lipids and saponins reduced lipid peroxidation of adipose tissue significantly. The amount of TBA-RS was tenfold higher in the adipose tissue than in the skeletal muscle, and might be more relevant in the prevention of diabetic complications associated with oxidative stress. This protection against oxidative stress is independent of lower blood glucose levels, as there was no significant correlation between glycated $\mathrm{Hb}$ levels and TBA-RS concentrations in the adipose tissue (Table 4).

The lipid fraction of BG contains a high amount of conjugated linolenic acids such as cis-9,trans-11, trans-13-18: $3^{(39)}$, which might be responsible for the protection against lipid peroxidation in the mice treated with the lipid fraction. In vitro, the addition of $0.05 \%$ of cis-9,trans-11, trans-13-18:3, extracted from BG seeds, effectively prevented lipid peroxidation in the plasma and LDL and VLDL molecules as well as in the membranes of erythrocytes of diabetic and healthy patients. The protection against lipid peroxidation could even be enhanced by increasing the concentration of cis-9,trans-11,trans-13-18: 3 to $0 \cdot 1 \%$ of the plasma $^{(40)}$.

Although the saponin and the lipid fractions of BG showed the clearest antidiabetic effects, the mice treated with the hydrophilic residue also had lower levels of glycated $\mathrm{Hb}$ and a lower PTP 1B activity in comparison with the control mice. These effects were NS, but may be the result of the significantly $(P=0.05)$ lower body weight of these mice compared with that of the control mice. As the concentration of the hydrophilic residue $(12.2 \%)$ in $\mathrm{BG}$ is higher than that of the saponin $(4.2 \%)$ or the lipid $(3.2 \%)$ fraction, the effect of the hydrophilic residue seems to be very important, considering the effect of BG fruit. However, the body weight-lowering effect of the hydrophilic compounds is not clear. According to the literature, BG contains water-soluble vitamins $^{(41)}$, which might exert positive effects.

The moderate dosage of $150 \mathrm{mg} / \mathrm{kg}$ body weight used in the present study was derived from the study done by Sathishsekar $\&$ Subramanian ${ }^{(42)}$. Especially, for the whole fruit powder, this dosage was very low compared with the dosages used by other authors in their studies, up to $10 \%(\mathrm{w} / \mathrm{w})$ of the $\operatorname{diet}^{(43)}$, which means a daily dosage of about $5000 \mathrm{mg} / \mathrm{kg}$ body weight. It is very likely that the effect of the whole fruit powder will be more pronounced with a higher dosage. But in particular for isolated fractions such as the saponin fraction, the lipid fraction or the hydrophilic residue, there seems to be an upper limit for the most effective dosage ${ }^{(30)}$. At high insulin concentrations (50 or $100 \mathrm{nmol} / \mathrm{l}$ ), BG juice and water or chloroform extracts of BG only show insulin-sensitising effects in vitro at low concentrations (10 $\mu \mathrm{g} \mathrm{BG/ml} \mathrm{medium)} \mathrm{and} \mathrm{inhibit} \mathrm{glucose} \mathrm{uptake}$ into L6-myocytes or 3T3-L1 adipocytes at concentrations higher than $50 \mu \mathrm{g} \mathrm{BG} / \mathrm{ml}$ medium dose dependently ${ }^{(2,3,27)}$. Therefore, in future studies, it is important to define the optimal dosage of $\mathrm{BG}$ for rodents that is also a realistic dosage for patients, which is calculated as amount per $\mathrm{kg}^{0.75}$ body weight. 


\section{Conclusion}

The present study proves the effectiveness of BG in decreasing body weight gain, glycated $\mathrm{Hb}$ levels and oxidative stress in type 2 diabetic $\mathrm{db} / \mathrm{db}$ mice. It also indicates that there are a number of different bioactive compounds that are responsible for the different metabolic effects exerted by BG.

The identification of the substance groups with the highest effects, namely saponins and lipids, is important for developing supplements for the prevention and treatment of diabetes mellitus. Particularly in developing countries, where nutrition and dietary measures play a crucial role in the treatment of diabetes mellitus, BG represents a possible means for preventing and treating diabetes mellitus. BG is a cheap vegetable that is available the whole year at local markets in southern and eastern Asia and tropical Africa ${ }^{(31,44)}$. BG could also make a positive contribution to the medical treatment of diabetes in industrialised countries.

\section{Acknowledgements}

This work was funded by the Federal Ministry for Economic Cooperation and Development (Germany) and the Dannon Institute Nutrition for Health (Germany). There are no conflicts of interests. The study was planned and performed by S. D. K. and M. B. K. The animal trial including preparation of the diet was performed in collaboration with J. P.; Western blot analyses were performed in collaboration with A. S. M. All authors were involved in the preparation of the paper.

\section{References}

1. Zimmet P, Alberti KGMM \& Shaw J (2001) Global and societal implications of the diabetes epidemic. Nature 414, 782-787.

2. Cummings E, Hundal HS, Wackerhage H, et al. (2004) Momordica charantia fruit juice stimulates glucose and amino acid uptakes in L6 myotubes. Mol Cell Biochem 261, 99-104.

3. Singh J, Adeghate E, Cummings E, et al. (2004) Beneficial effects and mechanism of action of Momordica charantia juice in the treatment of streptozotocin-induced diabetes mellitus in rat. Mol Cell Biochem 261, 63-70.

4. Basch E, Gabardi S \& Ulbricht C (2003) Bitter melon (Mormordica charantia): a review of efficacy and safety. Am J Health Syst Pharm 60, 356-359.

5. Krawinkel MB \& Keding GB (2006) Bitter gourd (Momordica charantia): a dietary approach to hyperglycemia. Nutr Rev $\mathbf{6 4}$, $331-337$.

6. Oishi Y, Sakamoto T, Udagawa H, et al. (2007) Inhibition of increases in blood glucose and serum neutral fat by Momordica charantia saponin fraction. Biosci Biotechnol Biochem 71, $735-740$.

7. Nerurkar PV, Lee YK, Motosue M, et al. (2008) Momordica charantia (bitter melon) reduces plasma apolipoprotein B-100 and increases hepatic insulin receptor substrate and phosphoinositide-3 kinase interactions. Br J Nutr 100, 751-759.

8. Miura $\mathrm{T}$, Itoh $\mathrm{C}$, Iwamoto $\mathrm{N}$, et al. (2001) Hypoglycemic activity of the fruit of the Momordica charantia in type 2 diabetic mice. J Nutr Sci Vitaminol (Tokyo) 47, 340-344.

9. Müller AS, Bosse AC, Most E, et al. (2009) Regulation of the insulin antagonistic protein tyrosine phosphatase $1 \mathrm{~B}$ by dietary Se studied in growing rats. J Nutr Biochem 20, 235-247.

10. Clampit JE, Meuth JL, Smith HAT, et al. (2003) Reduction of protein-tyrosine phosphatase-1B increases insulin signaling in
FAO hepatoma cells. Biochem Biophys Res Commun 300, 261-267.

11. Ahmad F, Azevedo JL, Cortright R, et al. (1997) Alterations in skeletal muscle protein-tyrosine phosphatase activity and expression in insulin-resistant human obesity and diabetes. $J$ Clin Invest 100, 449-458.

12. Mohammad A, Wang J \& McNeill JH (2002) Bis(maltolato) oxovanadium(IV) inhibits the activity of PTP1B in Zucker rat skeletal muscle in vivo. Mol Cell Biochem 229, 125-128.

13. Elchebly M, Payette P, Michaliszyn E, et al. (1999) Increased insulin sensitivity and obesity resistance in mice lacking the protein tyrosine phosphatase-1B gene. Science 283, 1544-1548.

14. Klaman LD, Boss O, Peroni OD, et al. (2000) Increased energy expenditure, decreased adiposity, and tissue-specific insulin sensitivity in protein-tyrosine phosphatase 1B-deficient mice. Mol Cell Biol 20, 5479-5489.

15. Gum RJ, Gaede LL, Koterski SL, et al. (2003) Reduction of protein tyrosine phosphatase $1 \mathrm{~B}$ increases insulin-dependent signaling in ob/ob mice. Diabetes 52, 21-28.

16. Chao CY \& Huang CJ (2003) Bitter gourd (Momordica charantia) extract activates peroxisome proliferator-activated receptors and upregulates the expression of the acyl CoA oxidase gene in H4IIEC3 hepatoma cells. J Biomed Sci 10, 782-791.

17. Chuang CY, Hsu C, Chao CY, et al. (2006) Fractionation and identification of $9 c, 11 t, 13 t$-conjugated linolenic acid as an activator of PPARalpha in bitter gourd (Momordica charantia L.). J Biomed Sci 13, 763-772.

18. NRC (National Research Council) (1995) Nutrient Requirements of Laboratory Animals, 4th revised ed. Washington, DC: National Academy Press.

19. Wilmanns von W, Sauer H \& Gelinsky P (1969) Beziehung zwischen enzymatischer Formiataktivierung und Erythrozytenlebensdauer (Relationship between enzymatic formate activation and erythrocyte lifespan). Blut XIX, 457-469.

20. Zhu L \& Goldstein B (2002) Use of an anaerobic chamber environment for the assay of endogenous cellular proteintyrosine phosphatase activities. Biol Proced Online 4, 1-9.

21. Bradford MM (1976) A rapid and sensitive method for the quantitation of microgram quantities of protein utilizing the principle of protein-dye binding. Anal Biochem 2, 248-254.

22. Chomczynski P \& Sacchi N (1987) Single-step method of RNA isolation by acid guanidinium thiocyanate-phenol-chloroform extraction. Anal Biochem 162, 156-159.

23. Wong SHY, Knight JA, Hopfer SM, et al. (1987) Lipoperoxides in plasma as measured by liquid-chromatographic separation of malondialdehyde-thiobarbituric acid adduct. Clin Chem 33, $214-220$

24. Khoschsorur GA, Winklhofer-Roob BM, Rabl H, et al. (2000) Evaluation of a sensitive HPLC method for the determination of malondialdehyde, and application of the method to different biological materials. Chromatographia 52, 181-184.

25. Yibchok-Anun S, Adisakwattana S, Yao CY, et al. (2006) Slow acting protein extract from fruit pulp of Momordica charantia with insulin secretagogue and insulinomimetic activities. Biol Pharm Bull 29, 1126-1131.

26. Huang HL, Hong YW, Wong YH, et al. (2008) Bitter melon (Momordica charantia L.) inhibits adipocyte hypertrophy and down regulates lipogenic gene expression in adipose tissue of diet-induced obese rats. Br J Nutr 99, 230-239.

27. Roffey BW, Atwal AS, Johns T, et al. (2007) Water extracts from Momordica charantia increase glucose uptake and adiponectin secretion in 3T3-L1 adipose cells. J Ethnopharmacol 112, 77-84.

28. Yibchok-Anun S, Adisakwattana S, Yao CY, et al. (2006) Slow acting protein extract from fruit pulp of Momordica charantia with insulin secretagogue and insulinomimetic activities. Biol Pharm Bull 29, 1126-1131. 
29. Tan MJ, Ye JM, Turner N, et al. (2008) Antidiabetic activities of triterpenoids isolated from bitter melon associated with activation of the MAPK pathway. Chem Biol 15, 263-273.

30. Cheng HL, Huang HK, Chang CI, et al. (2008) A cell-based screening identifies compounds from the stem of Momordica charantia that overcome insulin resistance and activate AMP-activated protein kinase. J Agric Food Chem 56, 6835-6843.

31. Sridhar MG, Vinayagamoorthi R, Arul Suyambunathan V, et al. (2008) Bitter gourd (Momordica charantia) improves insulin sensitivity by increasing skeletal muscle insulin-stimulated IRS-1 tyrosine phosphorylation in high-fat-fed rats. $\mathrm{Br} \mathrm{J} \mathrm{Nutr}$ 99, 806-812.

32. Greer JJM, Ware DP \& Lefer DJ (2005) Myocardial infarction and heart failure in the $\mathrm{db} / \mathrm{db}$ diabetic mouse. Am J Physiol Heart Circ Physiol 290, 146-153.

33. Nieto-Vazquez I, Fernández-Veledo $\mathrm{S}$, de Alvaro $\mathrm{C}$, et al. (2007) Protein-tyrosine phosphatase 1B-deficient myocytes show increased insulin sensitivity and protection against tumor necrosis factor- $\alpha$-induced insulin resistance. Diabetes 56, 404-413.

34. Ojewole JA, Adewole SO \& Olayiwola G (2006) Hypoglycaemic and hypotensive effects of Momordica charantia Linn (Cucurbitaceae) whole-plant aqueous extract in rats. Cardiovasc J South Afr 17, 227-232.

35. Samane S, Noël J, Charrouf Z, et al. (2006) Insulin-sensitizing and anti-proliferative effects of Argania spinosa seed extracts. Evid Based Complement Altern Med 3, 317-327.

36. Mahomoodally MF, Fakim AG \& Subratty AH (2004) Momordica charantia extracts inhibit uptake of monosaccharide and amino acid across rat everted gut sacs in-vitro. Biol Pharm Bull 27, 216-218.

37. Denu JM \& Tanner KG (1998) Specific and reversible inactivation of protein tyrosine phosphatases by hydrogen peroxide: evidence for a sulfenic acid intermediate and implications for redox regulation. Biochemistry 37, 5633-5642.

38. Delibegovic M, Bence KK, Mody N, et al. (2007) Improved glucose homeostasis in mice with mucle-specific deletion of protein-tyrosine-phosphatase 1B. Mol Cell Biol 27, 7727-7734.

39. Suzuki R, Arato S, Noguchi R, et al. (2001) Occurrence of conjugated linolenic acid in flesh and seed of bitter gourd. J Oleo Sci 50, 753-758.

40. Dhar P, Chattopadhyay K, Bhattacharyya D, et al. (2007) Antioxidative effect of conjugated linolenic acid in diabetic and non-diabetic blood: an in vitro study. J Oleo Sci 56, 19-24.

41. Njoroge GN \& van Luijk MN (2004) Momordica charantia L. (Internet) Record from Protabase [GJH Grubben and OA Denton, editors]. Wageningen: PROTA (Plant Resources of Tropical Africa/Ressources végétales de l'Afrique tropicale). http://database.prota.org/search.htm (accessed 13 April 2010).

42. Sathishsekar D \& Subramanian S (2005) Beneficial effects of Momordica charantia seeds in the treatment of STZ-induced diabetes in experimental rats. Biol Pharm Bull 28, 978-983.

43. Kumar Shetty A, Suresh Kumar G \& Veerayya Salimath P (2005) Bitter gourd (Momordica charantia) modulates activities of intestinal and renal disaccharidases in streptozotocin-induced diabetic rats. Mol Nutr Food Res 49, 791-796.

44. Sekar DS, Sivagnanam K \& Subramanian S (2005) Antidiabetic activity of Momordica charantia seeds on streptozotocin induced diabetic rats. Pharmazie 60, 383-387. 